\title{
Disease warning models for brown rot fungi of fruit crops
}

\author{
Holb, I.J. \\ Centre for Agricultural Sciences, University of Debrecen 138 Böszörményi St., 4032 Debrecen, Hungary
}

\begin{abstract}
Summary: In this review, disease warning models for brown rot fungi, including Monilinia fructigena, M. laxa and M. fructicola, were summarized. Few studies have been made to relate epidemiology and disease warning in brown rot infection caused by M. fructicola and M. laxa in order to predict infections or develop decision support models for fungicide applications during the growing season. More recently a disease warning model and a decision support system were also performed for M. fructigena for organic apple orchards. This review gives an overview on some details of the above disease warning models and decision support system.
\end{abstract}

Key words: Monilinia spp., disease warning, forecasting, brown rot forecasting and management strategy, BRFMS

\section{Introduction}

Today, there is little doubt that disease warning system as a part of plant disease epidemiology provides the key to the most effective approach to disease control. Plant disease epidemiology is the overall study of disease epidemics, the comprehensive analysis of the interaction among three constituents: the host, the pathogen and the environment (Van der Plank, 1963; Zadoks \& Schein, 1979). Since the early nineteenth century, the epidemiology of fruit pathogens including Monilinia spp. has been studied thoroughly. Rapid development of our knowledge on the epidemiology of brown rot fungi started at the end of World War II. For fifty years, research into several parts of the brown rot disease cycles has been conducted and the results have been involved in disease management practice. For the last two decades, the complexity of brown rot epidemics, including molecular examinations, the spatio-temporal modelling approach, disease threshold and disease warning, has been involved in most epidemiological studies.

The aim of this review paper was to summarise disease warning models for brown rot fungi, including Monilinia fructigena (Aderh. \& Ruhl.) Honey, M. laxa (Aderh. \& Ruhl.) Honey and M. fructicola (Wint.) Honey (Holb, 2003ab).

\section{Disease warning models}

Disease warning is partly about defining the conditions under which a pathogen, when in contact with a susceptible host, can infect and become established (Zadoks \& Schein, 1979, Batra, 1991). However, disease warning schemes require, as their components, data on and an understanding of the epidemiology of the diseases and pathogens. Moreover, understanding the interaction of host, inoculum and environment is essential for devising suitable disease warning or decision support systems. Such a system was developed for fruit diseases, such as apple scab, apple powdery mildew and fire blight. Few studies have been made to relate epidemiology and disease warning in brown rot infection caused by $M$. fructicola and M. laxa in order to predict infections or develop decision support models for fungicide applications during the growing season. More recently disease warning model and decision support system were performed for M. fructigena for organic apple orchards. However, no disease warning model has been constructed for M. polystroma.

Luo et al. (2001a,b) developed a risk analysis system for blossom blight of prune caused by M. fructicola. A risk assessment table (Figure 1) of blossom blight was produced for different environmental conditions to guide the control of prune brown rot.

The diagram is based on bloom stage, inoculum concentration, and temperature. The risks were classified into four levels: no risk, low, moderate, and high risk; according to values of relative risk. There was no risk of blossom blight at early bloom stage (from popcorn to full bloom) when temperature was below $10^{\circ} \mathrm{C}$ and wetness duration was shorter than 4 hours (Figure 1). When wetness duration was $24 \mathrm{~h}$, there was a high relative risk of blossom blight at 20 and $25^{\circ} \mathrm{C}$ when inoculum potential was low or at 15 and $20^{\circ} \mathrm{C}$ when inoculum potential was high. Fewer cases with a high relative risk occur at late bloom stage (from late full bloom to petal fall) than at early bloom stage. Only the 24 -hour wetness duration at $20^{\circ} \mathrm{C}$ with either low or high inoculum potential may be associated with severe blossom blight. Most conditions resulted in low to moderate risk of blossom blight. Luo \& Michailides (2001) developed a similar risk analysis system for latent infection of prune caused by $M$. fructicola. Another study on phenological analysis of brown rot blossom blight of sweet cherry, caused by M. laxa, was made by Tamm et al. (1995). They investigated the influence of temperature and wetness duration on infection incidence of sweet cherry blossoms in Switzerland. They combined Richards and Analytis' beta models into a nonlinear 


\begin{tabular}{|l|c|c|c|c|c|c|c|c|}
\hline Bloom & Inoculum & Temperature & \multicolumn{5}{|c|}{ Wetness duration } & \\
\hline stage & potential & $\left({ }^{\circ}\right.$ C) & $\mathbf{4}$ & $\mathbf{8}$ & $\mathbf{1 2}$ & $\mathbf{1 6}$ & $\mathbf{2 0}$ & $\mathbf{2 4}$ \\
\hline popcorn & low $^{x}$ & 10 & & & & & & \\
\hline to full & & 15 & & & & & & \\
\hline bloom & & 20 & & & & & & \\
\hline & & 25 & & & & & & \\
\hline & high & 10 & & & & & & \\
\hline & & 15 & & & & & & \\
\hline & & 20 & & & & & & \\
\hline & & 25 & & & & & & \\
\hline late full & low & 10 & & & & & & \\
\hline bloom to & & 15 & & & & & & \\
\hline petal fall & & 20 & & & & & & \\
\hline & & 25 & & & & & & \\
\hline & high & 10 & & & & & & \\
\hline & & 15 & & & & & & \\
\hline & & 20 & & & & & \\
\hline & & 25 & & & & & \\
\hline
\end{tabular}

\begin{tabular}{|l|l|}
\hline & No risk \\
\hline & Low risk \\
\hline & Moderate risk \\
\hline & High risk \\
\hline
\end{tabular}

Figure 1 Relative risks of blossom blight of prunes caused by Monilinia fructicola in relation to different bloom stages, inoculum potentials, temperatures, and wetness durations (adapted from Luo et al., 2001b)

\begin{tabular}{|c|c|c|c|c|c|}
\hline \multirow{6}{*}{ 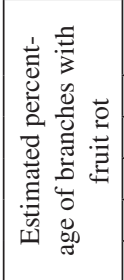 } & & \multicolumn{4}{|c|}{$\begin{array}{l}\text { Relative probability of leading latent infection to } \\
\text { fruit rot }\end{array}$} \\
\hline & & $<50$ & $50-80$ & $81-90$ & $>90$ \\
\hline & $<1.0$ & & & & \\
\hline & $1.0-5.0$ & & & & \\
\hline & $5.1-10.0$ & & & & \\
\hline & $>10.0$ & & & & \\
\hline
\end{tabular}

\begin{tabular}{|l|l|}
\hline & Safe, no fungicide application is needed \\
\hline & Wait, continue to investigate latent infections \\
\hline $\begin{array}{l}\text { Refer to historical weather to determine } \\
\text { necessity of fungicide application }\end{array}$ \\
\hline Spray fungicide immediately \\
\hline
\end{tabular}

Figure 2 Diagram of decision process used in the decision support model for fungicide application to reduce risk of prune fruit rot caused by Monilinia fructicola (adapted from Luo \& Michailides, 2003)

model to describe the infection incidence as a function of both temperature and wetness duration. The model was used to predict the possible range of incidence of blossom blight resulting from combinations of different temperatures and wetness durations.

In a recent study, Luo \& Michailides (2003) developed a preliminary decision support model to guide fungicide application to reduce risk of prune fruit rot caused by Monilinia fructicola. The estimated percentage of branches with fruit rot and relative probability of leading latent infection to fruit rot were used to develop the decision process
(Figure 2). Four recommendations for disease management were used:

- safe, no need of fungicide application in the season;

- wait, continue to investigate latent infection;

- check reference of historical weather to decide if fungicide application is needed;

- and spray fungicide immediately.

In a more recent study Holb et al. (2011) prepared a brown rot forecasting disease management strategy for $M$. fructigena for organic apple orchard. In this five-year-study, temporal development of brown rot on fruits was analysed in two organic apple orchards. Disease variables of $Y_{f}$ the final disease incidence; $\beta$ relative rate of disease progress; $A U D P C_{S}$, standardized area under disease progress curve; $T_{1.5}$, is the time when disease incidence reaches $1.5 \%$ (day), and $M$, is the inflection point were derived from the threeparameter logistic function. The disease variables of $Y_{f}, \beta$, and $A U D P C_{S}$ were used in a computer simulation for predicting temporal brown rot development, and the disease variables of $T_{1.5}, M$, and $Y_{f}$ were used to determine threshold values for epidemic intensity. Then these were used to construct a fundamental model for developing a brown rot forecasting and management strategy (BRFMS, Figure 3). The fundamental model contained four parts i) data insertation and analyses by computer simulation of pathogen submodels, ii) calculation of yield loss threshold levels based on disease incidence, iii) determination epidemic intensity levels and iv) decision modul with suggestions of disease management practices for each epidemic intensity level.

Centre of the model is the computer simulated pathogen submodels, which requires insertation of field data and data analyses methods for prediction purposes. Collected data form the field of a prediction year (weekly assessed fruit brown rot incidence, weather parameters) and analyses methods inluding mathematical functions and derived parameters (AR6 model for spore dispersal; correlation coefficients for weather parameters; three-parameter Gompertz function for relationship between spore dispersal and corresponding disease incidence, maximum values of $A U D P C_{S}, Y_{f}$ and $\beta$ derived from temporal brown rot progress curves) need to be inserted into the computer-based simulation program (Fig. 3). A preliminary three-parameter logistic function is generated by the simulation program after the fourth assessment date, and $A U D P C_{S}, Y_{f}$ and $\beta$ are calculated from the function for the given date. Then these calculated values of $A U D P C_{s}, Y_{f}$ and $\beta$ should be compared with the given maximum values inserted into the simulation program at the beginning. If the calculated values reach the given values, then three threshold values of the brown rot development can be calculated: i) the first threshold value is the time when disease incidence reaches $1.5 \%\left(T_{1.5}\right)$, ii) the second threshold value is the inflection point $(M)$, and iii) the third threshold value is the final disease incidence $\left(Y_{f}\right)$. Each threshold value corresponds to an epidemic intensity level which ranges between lower asymptote $\left(Y_{0}\right)$ and $T_{1.5}$ for the first level (beginning of disease development), between $T_{1.5}$ and $M$ for the second level (increasing phase of disease 
BROWN ROT SPECIFIC ANALYSES METHODS:

i) $\mathrm{AR}(6)$ model for spore dispersal,

ii) Weather-spore dispersal correlation coefficients,

iii) Gompertz-function for spore-symptom relationship, iv) $A U D P C_{S}, Y_{f}, \beta$ (max.).

\section{Prediction of occurrence of first fruit rot symptom}

Detection of first fruit infection on the orchard floor

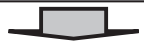

Application of lag period AUDPC (Holb and Scherm, 2007)

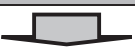

5-10 days earlier prediction of $T_{0}$ on the tree
BASIC DATA:

i) weekly assessed fruit brown rot incidence,

ii) weather parametersassessed.

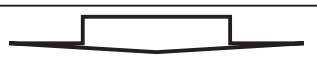

\section{Computer-based simulation program: pathogen submodel}

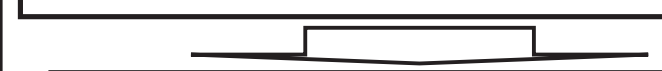

Fit three-parameter logistic function

Computer calculated
$A U D P C_{S}, Y_{f}, \beta$$\quad$ Given $A U D P C_{S}, Y_{f}, \beta$
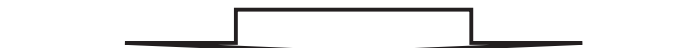

Threshold value

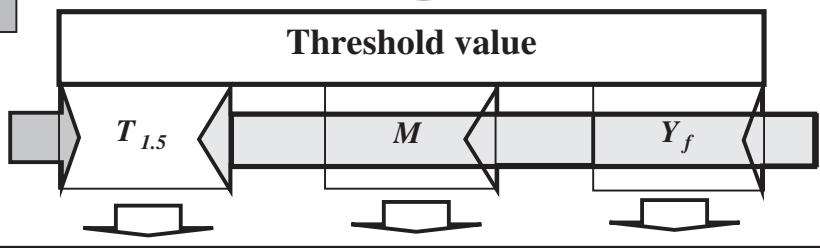

7-14 days earlier prediction of brown rot infected fruit

\section{Prediction of insect} injury on fruit

Monitoring of codling moth by pheromone trap

Relationship calculated between injured fruit and trapped moth (Holb and Scherm, 2008)

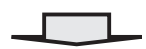

Number of injured fruit

Relationship calculated between injured fruit and rotted fruit (Holb and Scherm, 2008)

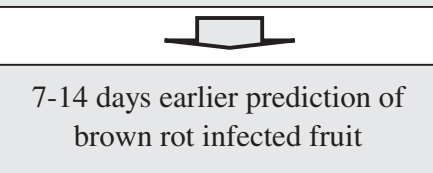

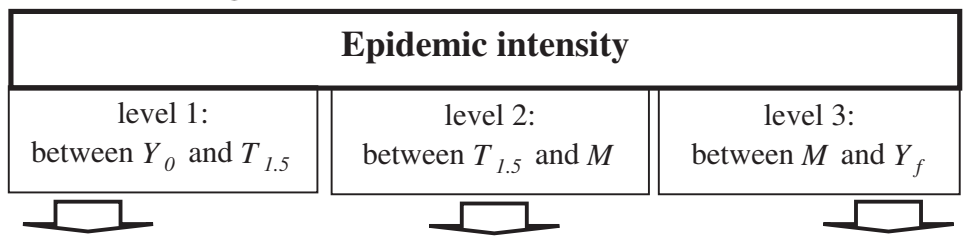

\section{Decision modul with disease management practices}

level 1 (lag phase):

- timing of first fungicide spray

- insect control based on injury prediction

- removal of dropped fruit according to

Holb and Scherm (2007)

\section{level 2 (log phase):}

- insect control based on injury prediction

- fungicide spray based on prediction - weekly removal of infected fruit from the tree and orchard floor level 3 (terminal phase):

- insect control based on injury prediction - intensive fungicide spray to reduce postharvest rot - removal of infected fruit

Figure 3 A brown rot forecasting and management strategy (BRFMS) against Monilinia fructigena for organic apple orchards. Explanations: AR6 model: autoregressive model with six autoregressive parameters, $A U D P C$ : area under the disease progress curve (\%-days) $A U D P C_{s}$ : standardized area under the disease progress curve (\%-days), $Y_{f}$ is the final disease incidence $(\%), \beta$ : is the relative rate variable $\left(\right.$ day $\left.^{-1}\right), T_{0}$ : is the time when the fruit first symptoms occurs on the tree (day), $T_{15}$ : is the time when disease incidence reaches $1.5 \%$ (day), and $M$ : is the inflection point, measured in days. (Adopted from Holb et al., 2011)

development), and between $M$ and $Y_{f}$ for the third level (final phase of disease development).

An essential threshold and epidemic intensity part of the BRFMS is the timing of first spray against fruit rot by predicting the occurrence of first infected fruit on the tree (Fig. 4). In the first step, assessment of first infected fruit on the orchard floor need to be inserted into the pathogen submodel then according to the method of Holb and Scherm (2007) on lag period of AUDPC between fruit rot incidence on the orchard floor and on the tree need to be applied to predict first symptom appearance $\left(T_{0}\right)$ on the tree. The predicted $T_{0}$ can be used in the first level of epidemic intensity and time the first fungicide spray against brown rot. With this approach, 5-10 days prediction of appearance of first symptoms can be achieved.

The success of BRFMS in the three epidemic intensity levels is largely dependent upon the prediction of insect injury (Fig. 3). In our model, counts of codling moth adults from pheromone trap are suggested to collect as basic data set. From this data insect injured fruit can be predicted by regression equations express relationship between injured fruit and trapped moth and then actual brown rot incidence 
can achieved by applying regression equations of Holb and Scherm (2008) for the relationship between injured fruit and brown rot incidence. With this approach, 7-14 days earlier prediction of a newly infected, injury related fruit can be achieved in all epidemic intensity levels.

Then, in the decision modul, brown rot management practices can be suggested throughout the three of epidemic intensity levels (Fig. 3). In the period of the first epidemic intensity level, timing of first fungicide spray, preventive insect spray programs based on injury prediction can be applied as well as removal of dropped fruits according to the study of Holb and Scherm (2008). In the period of the second epidemic intensity level, fungicide spray based on model prediction, insect spray programs based on injury prediction and weekly removal of infected fruits from the tree and from the orchard floor is needed. In the period of the third epidemic intensity level, continuous insect spray programs followed based on injury prediction, intensive brown rot spray programs applied to reduce postharvest rot and removal of infected fruits can be sufficient for brown rot management.

In a three-year field evaluation, season-long application of BRFMS treatments reduced the number of sprays against brown rot by $22.2-33.3 \%$ compared with the treatments of general spray schedules against brown rot.

\section{Acknowledgements}

This research was partly supported by grants of the Hungarian Scientific Research Fund (K78399) and the NKTHOM-00227/2008 as well as by a János Bolyai Research Fellowship awarded to Imre J. Holb..

\section{References}

Batra, L. R. (1991): World species of Monilinia (Fungi): their ecology, biosystematics and control. Mycologia Memoir No. 16, J. Cramer, Berlin, 246 pp.
Holb I. J. (2003a): Analyses of temporal dynamics of brown rot development on fruit in organic apple production. International Journal of Horticultural Science 9 (3-4): 97-100.

Holb I. J. (2003b): The brown rot fungi of fruit crops (Monilinia spp.) I. Important features of their biology (Review paper). International Journal of Horticultural Science 9 (3-4): 23-36.

Holb, I.J., \& Scherm, H. (2007): Temporal dynamics of brown rot in different apple management systems and importance of dropped fruit for disease development. Phytopathology, 97, 1004-1111. doi: 10.1094/PHYTO-97-9-1104

Holb, I.J., \& Scherm, H. (2008): Quantitative relationships between different injury factors and development of brown rot caused by Monilinia fructigena in integrated and organic apple orchards. Phytopathology, 98, 79-86. doi: 10.1094/ PHYTO-98-1-0079

Holb IJ, Balla B, Abonyi F, Fazekas M, Lakatos P \& Gáll, JM (2011): Development and evaluation of a model for management of brown rot in organic apple orchards. European Journal of Plant Pathology 129: 469-483.

Luo Y. \& Michailides, T. J. (2001): Risk analysis for latent infection of prune by Monilinia fructicola in California. Phytopathology 91 (12): 1197-1208.

Luo, Y. \& Michailides, T. J. (2003): Threshold conditions that lead latent infection to prune fruit rot caused by Monilinia fructicola. Phytopathology 93 (1): 102-111.

Luo, Y., Ma, Z. \& Michailides, T. J. (2001a): Analysis of factors affecting latent infection and sporulation of Monilinia fructicola on prune fruit. Plant Disease 85: 999-1003.

Luo, Y., Morgan, D. P. \& Michailides, T. J. (2001b): Risk analysis of brown rot blossom blight of prune caused by Monilinia fructicola. Phytopathology 91 (8): 759-768.

Tamm, L., Minder, C. E. \& Flückiger, W. (1995): Phenological analysis of brown rot blossom blight of sweet cherry caused by Monilinia laxa. Phytopathology 85: 401-408.

Van der Plank, J. E. (1963): Plant diseases: Epidemics and control. Academic Press, New York, USA. 344 pp.

Zadoks, J. C. \& Schein, R. D. (1979): Epidemiology and plant disease management. Oxford University Press, New York, USA. $428 \mathrm{pp}$. 